DOI: $10.1515 /$ pof-2015-0005

VOLUME 7, ISSUE 1, 2015

ISSN: $2036-5438$

\title{
Margins of Nationality. \\ External ethnic citizenship and non-discrimination \\ by
}

Kriszta Kovács, Zsolt Körtvélyesi, and Alíz Nagy*

Perspectives on Federalism, Vol. 7, issue 1, 2015 


\begin{abstract}
People are usually born into their political communities, and only a minority of them become member of the given community by naturalisation. Sovereign states enjoy a great margin of appreciation in defining the rules of both birthright and acquired political membership. Most states employ some form of cultural affinity-based criteria relating to ethnic identity that differentiate between applicants that seek to acquire the nationality of the state. Indeed, such distinctions seem to be growing with the revival of ethnic and nationalist aspirations that Europe has witnessed for some years. We argue that human rights principles, first and foremost non-discrimination guarantees, should be taken seriously and effectively applied to these cases of naturalisation, and show what such a scrutiny entails. While the arguments presented here should apply more generally, special attention will be paid to events that primarily triggered the authors' interest, the case of Hungary.
\end{abstract}

Key-words

State sovereignty, naturalisation policy, legitimacy, cultural affinity, non-discrimination principle, Hungary 


\section{Introduction}

Various forms of citizenship, and its legal counterpart, nationality, define membership in legal and political communities, but also, by this very move, define the boundaries of these communities, making the individual and the collective aspects inseparable. Different levels of governments only make sense with these communities defined. Accordingly, it is a question of primary importance, who has the authority to define these boundaries and what the possible limitations are on this power. With the growing importance of international and supranational human rights guarantees (most importantly the EU and the Council of Europe), various bodies can set limit to national citizenship policies.

Traditionally, international law has seen nationality as belonging to the core of national sovereignty, the 'domaine réservé' of states, implying an almost complete freedom from external interference. Constraints apply only in cases where a state seeks international (legal) recognition of its relationship to an individual (above all diplomatic and consular protection), and even in such cases, the mere showing of an existing (genuine) connection seems to suffice. This requirement can be seen as a 'positive' element, defining when states can recognize someone as a national. It does not say anything about possible 'negative' limitations, where states might be obliged to recognize someone as a national, against their will. Here, human rights law presents a potential ground for interference with naturalisation policies.

First, the 'right to nationality' has been codified. ${ }^{\mathrm{I}}$ Yet, this works less as a practical constraint on state policies (as a clear individual claim obliging a particular state would) and more as a general obligation of states to work towards the elimination of statelessness. Second, the non-discrimination principle should apply to all decisions that concern individual rights and obligations. As a relative principle, the non-discrimination principle can be placed between 'positive' and 'negative' limitations on state power, establishing constraints that potentially cut both ways: when states should refrain from granting citizenship and in cases where they ought to grant recognition. Human rights standards have changed the landscape of national citizenship policies. It used to be a general practice, e.g., to differentiate between men and women, in questions of citizenship, reinforcing the vulnerability of women in case of divorce. States with citizenship policies that discriminate 
against women are clear outliers. But to this day, most states continue to apply some form of cultural affinity-based criteria that differentiates between applicants that seek to acquire the nationality of the state, and there seems to be a reluctance to apply non-discrimination rules, with their full force, to such cases.

The present article argues for the general application of the non-discrimination principle to ethnic citizenship policies. It will proceed by first introducing the role of citizenship in defining the political community, the 'right' people and, second, by analysing what political goals can serve as legitimate grounds for citizenship policies. We apply a normative, human rights test to this end. While the arguments should apply more generally, special attention will be paid to events that primarily triggered the authors' interest, the case of Hungary. Recently the Hungarian government offered Hungarian citizenship to ethnic trans-border Hungarians without a residency requirement. The extension of voting rights followed this move. The end of this paper examines the implementation of the rules conferring the status of citizenship for those living abroad.

The article builds on arguments from political and legal theory as well as the relevant case law of the human rights international fora. It addresses arguments that can be used both for and against the permissibility of external ethnic citizenship, in a way that they could be played out, e.g., in an ECHR case with a claimant challenging the state policy and a respondent government defending its selectivity. II In addition to these two layers the paper draws on a recent empirical research, which has shown the effects of the recent Hungarian extension of the citizenry. This is because we believe that only the three aspects combined (theory, standards as applied, empirical insight) can account for the complex processes that sustain naturalisation policies with strong ethnic preference. The paper uses the terms nationality and citizenship interchangeably, if not indicated otherwise. It applies the adopted terminology following Brubaker on the 'triadic nexus' of the three players: kin minorities, their home states (where they reside) and their kin-states (the majority/titular nation of which they belong on ethnic, linguistic, religious etc. grounds) (Brubaker 1996). When we write about external ethnic citizenship we understand the granting of nationality to non-resident aliens based on an ethno-cultural criteria. By ethno-cultural, we largely mean the ideal group for traditional European nation-building, still alive today, defined by traces that might include language, religion and some kind of an imagined common ancestry. ${ }^{\text {III }}$ 


\section{Who are the people?}

'One day Japan grants equal voting rights to the citizen of Norway so that they can elect a small party of Norwegians to the Japanese Diet if they wish. Then the Diet by majority vote levies taxes on Norwegian oil and directs its transfer to Japanese refineries' (Dworkin 2011: 380). This is the hypothetical example of the book of Ronald Dworkin's Justice for Hedgehogs, which among others deals with the traditional question: Who are the people? As Dworkin emphasizes, people want to be governed by people relatively like themselves, and it has been taken to justify many forms of tribalism and nationalism: of race, religion, language, and kinship. But there is no answer to the question on who the right people are. This is because the ideal of democracy already presupposes a political community. As a default nation-states exist and their boundaries are created and altered by geography, accidents of history, war or politics (Dworkin 2011: 381-382). In most cases we have acquired the political membership by virtue of birthplace or 'pedigree', in other cases by naturalisation. But in both cases it is the state, which decides on the boundaries of the given community. States are allocating political membership at birth usually according to parentage (ius sanguinis) and territoriality (ius soli). Naturalisation is 'the final step in the process of acquiring citizenship after birth' (Shachar 2012: 1012). In order to acquire postbirth membership in a desired country, the applicant must first reach its territory and establish lawful permanent residence (Shachar 2012: 1012).

The paper accepts the Rawlsian claim that the nation-states are the primary loci of political legitimacy and the pursuit of justice and that the sovereignty of these states are constrained internally by the moral equality of individuals who are subjects of the given states, that is, who live in the territory of the given states (Rawls 1993: 36). The government must treat all its citizens as equals in the sense that political decisions and arrangements must display equal concern for the fate of all. Becoming a member of a political community is a crucial factor in the determination of life chances. The fate and life of the citizens of a political community are interconnected. The state's basic political institutions elaborate the rules, which govern their life. Citizens pay taxes to cover the expenses of the political institutions, public services and the redistribution. As citizens we tend to give preference to each other's interests, and sometimes this 'preferential treatment' 
is justified. ${ }^{\mathrm{IV}}$ It is the principle of justice, which gives answer to the question whether the preferential treatment is acceptable or not in a given case.

Members of the political community are in different situations both in terms of their abilities and capacities, and their social background and economic conditions. It is the duty of the state to improve the social and economic position of disadvantaged groups so that their opportunities shall be more equal. The state measure does not mean privilege, or giving more rights, but state intervention in order to reduce the social support of negative discrimination and the differences leading to it. The purpose of these measures is the equation of group disadvantages, that is helping those who had in an unjust way got into a disadvantageous situation because of their belonging to a social group.

For instance, it is justified to employ preferential treatment if a social group cannot take part equally in the life of the political community, possibly but not necessarily because of structural discrimination, and if the inefficient political power of the group has become steady, because then the group exists separated, isolated from the political community. Accordingly, the term preferential treatment is not the synonym of a justified classification and its goal is never to benefit certain persons. The ultimate purpose of preferential treatment, by definition, is the elimination of inequalities of opportunity in society.

However, in the case of rules conferring the status of citizenship the applicants are not yet stakeholders of the given political community. Following Rainer Bauböck, stakeholders of a country could be those individuals, whose ongoing ties to the polity involve them deeply in its present political life and 'whose circumstances of life link their future wellbeing to the flourishing of a particular polity' (Bauböck 2007: 2422). They can have a claim to membership and to participate in collective decision-making processes.

What kind of standards should govern our relations to individuals applying for admission to our political community? Thomas Nagel offers universal human rights as the source of the constraints on the external exercise of sovereign state power (Nagel 2005: 136). Universal human rights as an important part of international rules and institutions serve as limitations to the dominant sovereignty of separate nation-states. This means that there are principles, which should govern the nation-states' decision-making when choosing the right kind of demos or extending the citizenry. For instance, a state decision cannot be arbitrary; it should have legitimate reason for offering a membership for those who live outside of the state. 
Since Aristotle citizenship has always been associated with political relations (Shachar 2012: 1003). It embodies a connection between the state and the individual, a legal link that should be a reflection of an actual relationship. This follows from the fact that nationality is a key element in defining the boundaries of the political community. Voting and candidacy are usually the privileges of nationals, and as rights they should be exercised by the right people. If political decision-making is seriously detached from stakeholders, this might end up putting the underlying political rights into risk. This is why we need standards to determine whether the extension of citizenry in a given case is morally right or wrong.

This standard could be equality, which has close connections with justice in general. Building upon Rawls' conception of the resource-egalitarian theory of equality, this paper provides normative foundations for its main thesis that common non-discrimination guarantees should be applied to the case of naturalisation and cultural affinity-based preferences. To be able to apply this principle to citizenship policies, to decide what counts as reasonable differentiation in state decisions on nationality, we first should establish what nationality is, and what it isn't. Only in relation to this can we analyse what are the legitimate goals of differentiation, and what can be seen as a proportionate measure to achieve these goals (based on the general test applied in international as well as domestic human rights adjudication). The legitimate goals of nationality are thus linked to the core of nationality: what it means in its essence.

\section{What is nationality? Non-discrimination and external ethnic citizenship}

\subsection{In search of standards}

This chapter applies the non-discrimination test to the case of external ethnic citizenship. This endeavour raises a number of preliminary questions. First, whether the non-discrimination test can be applied to naturalisation, a decision intimately linked to national sovereignty. Second, whether we can define a core meaning of nationality, against which we can then measure what counts as legitimate policy goal and what does not.

Before proceeding further we should clarify what we mean with the term 'discrimination'. One can differentiate between three different types of discrimination. The first of these three dimensions involves ensuring equal treatment of equal situations and 
prohibiting the equal treatment of manifestly unequal situations. In order to avoid arbitrariness, governments should determine the criteria for the distribution of the entitlements and benefits with the same degree of consideration of individual interest. If there is a challenge to the validity of the government's policy choices, courts should judge the issue (e.g. tax, financial provisions) applying the reasonableness test. There should be an objective reason of the distinction. In the absence of such a reason, the distinction is arbitrary, since the affected persons were certainly not treated as persons with equal dignity. However, the weaker test of reasonable goal is not applicable for many characteristic cases of racial and ethnic discrimination and for cases that involve fundamental rights. In these cases it is only a test stronger than that of reasonable goal could detect that the classification is in fact discriminatory.

The second dimension of discrimination is the most grievous one. Strict equality is called for in the legal sphere of civil rights and freedoms, since there is no justification for any exception. All citizens of a society must have equal basic rights and fundamental liberties. However, to-be stakeholders are not yet citizens of the political community, and they do not have a fundamental right to gain nationality in a country chosen by them. Thus in ethnic citizenship cases such a right (gaining citizenship) which does not belong to the range of fundamental rights is at stake. Nevertheless, an arbitrary allocation or denial of nationality might in certain cases raise a fundamental rights issue because of the impact on e.g. the private life of the individual. ${ }^{\mathrm{V}}$

Citizenship cases include many characteristic features of ethnic and sex discrimination. We call this discrimination based upon bias, while this third type presupposes the illegitimacy of any differentiated treatment due to irrelevant criteria. Since classification based upon ethnicity is a suspect classification, in most jurisdictions heightened scrutiny is required to filter out illegitimate state measures. This standard seems to form a solid basis against which we can measure policies of external ethnic citizenship and it works well in several respects: it applies a general approach and 'forces' governments to justify their policies against a normative framework. This serves the additional goal of pressuring them to come forward with their justifications that are in line with human rights standards. ${ }^{\text {VI }}$ Most of the literature and the applicable case law on naturalisation and non-discrimination deal with the 'negative' aspect of naturalisation, or exclusion, about denial of citizenship to claimants, whereas we problematize here a 'positive' aspect, i.e. inclusion of groups of 
people based on ethno-cultural traits. This can also be interpreted as internal limits (whom states can exclude from the residents) with stricter (international) scrutiny, and external limits (whom states can include from among non-residents) with apparently less (international) scrutiny. Yet, underlining the statement that inclusion and exclusion are only the two sides of the same coin (Joppke 2005: 22-23), an imaginary claimant to a case designed following our arguments here would seek remedy for his or her exclusion for the lack of membership of the said groups. If the gap between the preferential and the nonpreferential track is too wide, also considering the basis of the differentiation, it can easily amount to discrimination based upon bias. To be sure, the non-discrimination requirement in itself will not outlaw all kinds of differentiation based on ethnicity, but places a heavy burden on the governments to justify their policies when they apply national or ethnic criteria. On the most general level, nationality can be described as a proxy. ${ }^{\text {VII }}$ A legislative act defines who is a national, and other acts confer certain rights and duties on these nationals (and not others). It is along these lines that external ethnic citizenship has been defended: after all, states are free to treat citizenship as a symbolic embodiment of ethnic belonging. Indeed, states are largely free to decide what rights and duties are attached to this status. For our purposes, however, the view that maintains the extreme elasticity (or even emptiness) of citizenship would make it hard to define a core meaning of what nationality is about. There are at least two arguments that can save us from this deadlock.

First, as we have seen, nationality is more than one status among many that links a state up to an individual. It is the defining membership for a political community, decisive both for the state (it acts in the name of whom, which people ${ }^{\mathrm{VIII}}$ ) and for the individuals (where and how they can exercise their political rights). While many elements have become detached from nationality (non-nationals can vote, can get elected, and can now exercise other rights reserved, earlier, to nationals), there is still a strong connection between nationality and membership in the political community. State practice underlines this view also in the context of external citizenship: many countries that opt for an extension of the citizenry to co-ethnics abroad also allowing them to vote. ${ }^{\mathrm{IX}}$ This necessarily means that the connection is more than mere symbolism. Second, international and European legal provisions do circumscribe something that seems to be essential elements of nationality. The 1930 Hague Convention, in its Article 1, says that states are bound to recognise other states' sovereign decision on whom their nationals are only insofar as this decision is in line 
with international law. ${ }^{\mathrm{x}}$ This makes it crucial to see what states and other actors on the international scene see as the core meaning of nationality. The International Court of Justice faced this question in its 1955 Nottebohm judgement, and concluded that nationality should be 'real and effective', adding that 'naturalisation is not a matter to be taken lightly. ${ }^{\text {XI }}$ This established the effective link or genuine connection criteria that have some bearing on what nationality is about, but all this is limited to the scope of international recognition. A state not respecting this principle might argue that it is aware of this limitation, and is willing to accept that it is only valid insofar as it remains strictly a connection between the individual and the state, without international ramifications. A more complete statement on what nationality is, in Europe, can be found in the 1997 European Convention on Nationality. ${ }^{\mathrm{XII}}$ The very definition of nationality in the Convention maintains that "nationality" means the legal bond between a person and a State and does not indicate the person's ethnic origin'. XIII The Convention, both in its preamble and in Article 5, applies the non-discrimination principle to all questions arising from nationality, including distinctions based on 'national or ethnic origin'. ${ }^{\text {XIV }}$ It also repeats some basic principles like national sovereignty on the one hand and conditions for international recognition on the other. As we have seen, states have wide discretion in matters of nationality, of defining the boundaries of the political community. Questions of political philosophy arise about how states can justify their rules of exclusion and inclusion, but in the context of regulating (access to) nationality, this in itself rarely raises constitutional legal problems. One area of law, that applies universally and requires such justifications, piercing the veil of national sovereignty, is the principle of nondiscrimination that is part of virtually all human rights instruments, on the international, European and national levels. The following section takes this principle seriously and assesses whether granting citizenship to non-residents based on ethnic preference can be justified along established standards, using the rights based test of requiring legitimate objectives (or 'necessity') as well as a proportionate relationship between these and the (mode of) interference, that is the applied classification: 'proportionality' or, in the parlance of the European Court of Human Rights, that the interference is 'necessary in a democratic society'. 


\subsection{Applying the non-discrimination test}

Regardless of whether we assess impermissible discrimination in a domestic constitutional setting or on the international level, we can largely move along the twoprong test of necessity and proportionality. Reconstructing the test applied by the ECtHR, the steps look as follows: ${ }^{\mathrm{xV}}$

1) whether there has been a difference in treatment between persons in similar situations;

2) whether there is objective and reasonable justification;

2a) whether it pursues a legitimate aim;

$2 \mathrm{~b}$ ) whether there is a reasonable relationship of proportionality between the means employed and the aim sought to be realised.

In the case of external ethnic citizenship policies, it will not be hard to establish that there is a difference in treatment: it is quite unique for states to grant citizenship to nonresident aliens, especially if this happens in large numbers. Distinctions based on ethnicity will be especially suspect for the Court: "Where the difference in treatment is based on race, colour or ethnic origin, the notion of objective and reasonable justification must be interpreted as strictly as possible' ${ }^{\mathrm{XVI}}$ Furthermore, in ECHR case law, rather than looking at mere intent or aim, the effect of the policy is enough to show that there is a difference in treatment ('indirect discrimination'). ${ }^{\text {XVII }}$ This will render suspect the seemingly neutral policies that many European states prefer to adopt when furthering the goals of their external ethnic citizenship policies. E.g., Romania and Hungary both apply legal clauses that seek to circumvent earlier border changes, in an indirect way, instead of using a direct ethnic condition. The Romanian clause simply talks about those who lost their nationality 'for reasons not imputable to them' or 'against their will'; the Hungarian law talks about applicants 'whose ancestor was a Hungarian citizen, or whose Hungarian origin can be presumed'. XVIII As showing the unequal effect will suffice under ECHR case law, it is enough here to conclude that external ethnic citizenship policies, in their actual application, enforce an ethnic preference, and we do not need to go into the details of the legal wording and interpretation. This is anyway in line with the legislative intent, an ethnic-nationalist vision of the state. The question of what is behind the policies already plays into the justification part of the test.

While ethnic preference triggers a stricter standard of review, the burden on the 
responding government might also turn on the continental trends that judges might identify. The ECtHR has maintained that the existence of a European consensus will inform the decision on what counts as acceptable justification. ${ }^{\mathrm{XIX}}$ These elements are inherently linked to the notion of a 'margin of appreciation', a concept that the ECtHR uses to describe the leeway it allows for national governments. Far from imposing uniformity, the Court enforces minimum standards. While the ground of differentiation (ethnic origin -- in most cases, present only indirectly in external citizenship policies) causes the margin to shrink, the policy area, nationality, widens the margin: it is, after all, a 'domaine réservé, long recognised as belonging to the core of national sovereignty. But regardless of whether the margin of appreciation will be wide or narrow, states will have a large discretion to decide who will become their nationals and who won't. But our question is exactly this: where can we draw the margin, what are the limits that human rights standards do set, in the context of ethnic preferences?

First we need to identify grounds for differential treatment. We should only be concerned with grounds that can be deemed legitimate, in line with human rights standards. Yet, in the case of naturalisation policy, this will not be too constraining. Almost anything other than outright racism would most likely suffice. Indeed, states themselves often consider nationality as something as a privilege more than a right. ${ }^{\mathrm{xx}}$ Let's see, from this aspect, the common explicit (and prima facie acceptable) justifications for external ethnic citizenship policies. Governments can use two different types of justifications, either based on arguments why the individual deserves its nationality (individual claim/benefit) or because this is furthering government policies (state goal). As individual rights based arguments are stronger players in the field of human rights scrutiny, let's first look into those.

1) One could argue that individuals that share the ethnic background of the majority (titular) nation of a country, regardless of whether they reside in the respective state, have a genuine link, an effective connection that ought to be or, at least, can be recognized, if the individuals so desire. Yet, when looking into what genuine link might mean, it remains dubious whether mere ethnic belonging would suffice, rather than being one factor among many that can indicate an adequately deep connection. ${ }^{\mathrm{xx}}$ Ethno-cultural proximity, if anything, might work as presumption of a certain type of connection but is not enough in itself. ${ }^{\mathrm{XXI}}$ But let's be more permissive and imagine for a second that we accept ethnocultural ties as a basis of effective link and we allow states not only to grant citizenship to 
co-ethnics abroad, but also recognise this connection as in line with international law. The major problem with this view is that it would upset the delicate balance of established minority rights standards that maintain the primary responsibility of the home state in securing minority rights, and limit the kin-state's ability to interfere directly. ${ }^{\text {xxII }} \mathrm{A}$ persistent defender could still object and argue that this might not be that bad, after all. It seems that we give an additional layer of protection for members of a potentially vulnerable group. Yet, if we think of recent examples of Russian interventions that have been defended, among others, on grounds of 'protecting fellow Russians', it is easy to see how the first step of additional protection easily slips into a second one, contributing to an increased securitization of minority rights. This, in turn, is hardly beneficial for minorities who normally seek to fight the perception that they present an inherent danger (because they are potentially disloyal) to the state they live in. ${ }^{\mathrm{XxIV}}$ Not to mention the issue that external citizenship weakens minority claims for self-governance by increased autonomy (Bauböck 2007). In the Hungarian case, the rights of Hungarians who naturalise from Austria, Slovakia and Ukraine without taking up residency in Hungary actually diminish in important respects. As these countries do not allow applicants to maintain their original nationality, they become nationals of another country, with the additional layer of EU citizenship only available in two of the three cases.

In other words it is, at best, a fallacy to think that it is an external measure, nonresident naturalisation that can address the ills of minority life. ${ }^{\mathrm{xxv}}$ Getting back to our original question of justification, it remains questionable whether the ethnic link would be enough to defend external citizenship policies from criticism concerning their legal justifications.

2) State governments can apply a somewhat more refined version of the ethnic argument and could argue that granting citizenship is simply a form of recognition that had earlier been denied from co-ethnics residing abroad. They share their 'national identity' with the majority of the kin-state, it should only be permissible to acknowledge that with official documents, that can include a passport, attesting their 'national belonging', having their names printed on their mother tongue ('written as it should be'). Many of these claims are more than legitimate. The primary function of minority rights is exactly to secure that these claims (e.g., right to recognition, right to use one's name) are met -- by the home state. The kin-state's ability is, for both legal and technical reasons, limited in this sense. ${ }^{\text {xvI }}$ 
We have seen earlier that external citizenship as a replacement or additional guarantee for minority rights contradicts some basic tenets of the present system. Furthermore, we have seen that nationality, according to the established legal view, is more than symbolism. While states can adopt policies that counter this, they can hardly use this deviation to justify their policies against external (domestic or international) human rights review.

3) State governments can still point to patterns of oppressive policies, persistent violations in home states, against which they seek to grant protection, remedying existing discrimination. After all, refugee law and, more recently, the concept of the Responsibility to Protect both seem not only to legitimise but also require the protection of third states. Yet, it is easy to see how the grounds of justification diverge in these cases. External protection is legitimate insofar as, in the individual case, it has been established that this is necessary: there has been a violation of human rights. We should not forget that in all of these cases, there is a national sovereignty argument on the other side, too (just like with the external citizenship policy of the kin-state): the home state could argue on similar grounds against external intervention in its relationship with its own resident citizen. Furthermore, diplomatic and consular protection in the case of dual nationals is limited by the principle of effective nationality, which defeats the goal of extending citizenship so as to provide some kind of external protection.

So it seems that while states might be free to adopt policies on general (not individualised) arguments of discrimination by home states, these cannot stretch existing boundaries and go against the sovereignty of home states. Just like we have seen earlier with minority rights based arguments, a contrary position would question the current setup of the international minority rights regime.

4) State governments could point to actual discrimination flowing from past injustices. In the Hungarian and Romanian case, the argument could go, former citizens were denied nationality. Hungary recognises descendants of its nationals as nationals, regardless of the number of generations, the ratio of Hungarian national ascendants, linguistic skills or, most importantly, residence. In contrast, this 'line of inheritance' is broken in the case of former nationals (and their descendants) that lost their Hungarian nationality as a result of the borders moving over their heads. As a direct result undoing this potentially expands the citizenry to 'Greater Hungary' and maybe beyond. Similarly, Romania grants nationality, through 'reacquisition', to former nationals that lived in 'Greater Romania'. ${ }^{\text {XVII }}$ ECHR 
case law recognizes and might even require the correction of 'factual inequalities'. XXVIII

The fallacy in these arguments follows that in earlier justifications: governments try to legitimise their policies by contrasting them with policies that they adopted themselves. Extending the citizenry through an indefinite line of generations, while permissible, hardly seems to be normatively justifiable. States might feel free to adopt such measures, but they can hardly use them as arguments to justify their otherwise questionable policies.

5) As we have indicated, external citizenship policies might be justified based on other basis than individual claims, showing that they serve legitimate state policy goals. Linking co-ethnics might be part of a fully legitimate immigration policy that takes into account demographic and economic reasons as well as an expectation of a certain degree of social integration. Immigration and naturalisation policies can use ethnicity, linguistic skills and other cultural elements as a crude predictor of social integration. A suspect classification can thus become a legitimate part of a policy measuring cultural proximity. The only problem is that this justification as a stated policy goal goes against the policy itself, both in rhetoric and in its actual form. If social integration is the goal and kins migrate, that would frustrate the goal of 'Greater Hungary/Romania', emptying the 'targeted territories' of coethnic population. Furthermore, concerning the prominent omission of the residence requirement, it is hard to explain why states do not use their leverage of the easy access to citizenship to actually attract these people.

6) Finally, governments could argue that, in a post-national phase, seeking to virtualize state borders, their policies are fully in line with what the EU seeks to build: a common space, a truly multicultural universe where national identities are freely recognized. The issue with this argument is that it seeks to slip through the part of the policy that is problematized in the first place by the non-discrimination standard. Rather than a truly European project of virtualizing borders, external ethnic citizenship policies draw new borders based on ethnic belonging. Contrary to the goal of justifying external citizenship policies, this argument is hardly more than a recognition of the goal of discrimination. The government that argues against homogenization in the home states ends up seeking the same type of internal homogeneity among its citizenry.

This will not render, however, all distinctions based on ethnicity (or 'cultural affinity') discriminatory. While we can ponder how far liberal constitutional regimes can go in seeking to maintain or establish some sort of internal homogeneity, in a legal assessment 
most of the resulting policies will pass the human rights tests commonly applied today, also considering that states will have some margin of appreciation.

Differentiation based on linguistic skills, familial connections, some degree of 'cultural knowledge set' (sought to be assessed in naturalisation tests) will most likely favour applicants who are closer, culturally, to the ideal citizen of the policy maker. Asking for a fee to start the procedure and the requirement of adequate resources (means of subsistence, trying to make sure that newly naturalised citizens will not be an undue burden on the welfare system) will disfavour the less wealthy. Yet, in themselves, these will most likely not constitute human rights violations, provided that the non-preferential naturalisation is kept adequately open for applicants who do not qualify for (ethno-cultural) preferential treatment.

Consider a case where the government of the home state is not opposed to the external citizenship of its resident nationals that belong to an ethnic minority group (as is the case with Hungarians living in Romania). Let's accept for a moment that arguments (justification no. 2 above) based on nationality as an expression of 'national identity' and on a view that non-resident kins following the political news of the kin-state, subject to cultural, linguistic and other policies of the kin-state targeting co-ethnics abroad justify the extension of the citizenry. Why would that go against any doctrine established in the name of human rights considerations?

To see why even this scenario is problematic, we need to move beyond the grounds of justification and move to a more demanding element to the test, proportionality. Proportionality is a relational term that requires in this case a proportionate relationship between the legitimate policy goal and the means employed, that is, the grounds of classification. In cases when fundamental rights are not at stake and the classification applied is not suspect it is sufficient to apply the weaker test of reasonable goal. However, giving ethnic preference for non-residents, e.g., as a recognition of their 'national identity' automatically means a differentiation based upon an immutable characteristic (ethnicity). Heightened scrutiny is appropriate, which requires a necessary relationship between classification and the compelling state goal, there should be no less discriminatory way to achieve the objective. Although to avoid underinclusivity (where all persons with the trait contribute to the harm but others do too) and overinclusivity (where all that contribute to the harm have the trait but some with the trait do not contribute) is important in every type 
of differentiation, it is even more crucial in cases of suspect classification. A substantially overinclusive or underinclusive classification tends to undercut the claim of the legislator that the classification serves legitimate political ends (Stone et al. 1996: 751). Regardless of which justification we accept from the list that we have seen earlier, we will see both underinclusivity and overinclusivity. Ethno-cultural proximity will be only a crude predictor both for potential social integration and for how invested someone is in the political community (following the stakeholder concept), leaving people out who should qualify and, at the same time, including people who would not qualify. While governments routinely apply such loose standards, in the case of ethnic preference, such laxity might prove to be fatal, regarding the non-discrimination test. This, in turn, will also depend on what is at stake: what difference does it make to be in or out of the preferential group?

A substantial view should then consider not only the external citizenship policy, taken in isolation, but also its relationship to the non-preferential track of naturalisation. This is why it matters how 'open' non-preferential naturalisation is. If the ground for differentiation (ethno-cultural proximity, through legislative assumptions and the way it is assessed in practice) cannot justify the distance between the preferential and the nonpreferential track, the policy will fail the proportionality test and should be seen as discriminatory. ${ }^{\text {XxIx }}$ In the Hungarian case, the non-preferential track includes a 3+8-year residency requirement (considering the registration of settlement in addition to the number of years required by the law directly applicable to naturalisations), while the ethnic preference gives full exemption from the condition of residency, allowing applicants to naturalise without having visited the country. Applicants relying on the ethnic preference have additional benefits like not being required to prove the means of subsistence and housing or to take the naturalisation test.

We argued that it is justified to take the non-discrimination principle seriously and apply the test to naturalisation policies, including external ethnic citizenship policies. Our analysis now concludes that once we take this route, it is hard to stop short of declaring such ethnic preference in violation of the non-discrimination principle, especially if access to citizenship for residents otherwise remains highly restrictive.

So far we have examined justifications that are the most likely to succeed on a nondiscrimination test. As these considerations show, however, what is really working in the background is a nation-building project that seeks to revisit history, to the extent possible 
(ie., without directly questioning existing state borders), and ('re-') establish a desired past through the means of citizenship policies. As the Hungarian case shows, these goals can go hand-in-hand with more direct political aims benefiting certain parties that seek to secure a loyal voting base with the extension of those eligible to vote, in which case justification under any human rights test is hardly an option.

\section{Case study of Hungary}

\subsection{Legislative history}

Our aim in this chapter is to have a deeper understanding of how direct political aims play into policy decisions and reasoning, an insight that should inform our judgment on the legitimacy of naturalisation norms.

The case study focuses on Transylvania, the region where most of those concerned by the new policy live. It is a part of Romania, with a Hungarian minority population of approximately 1.2 million. Two-thirds of all applications for preferential naturalisation and three-fifths of the applications for registration as a voter in the 2014 general elections came from here. ${ }^{\mathrm{xxx}}$ In addition, Romania recognises dual citizenship policy and it has large minorities in its neighbouring countries which gives us the possibility to compare the two countries' attitudes towards its minorities. After World War I as a result of the Trianon Peace Treaty Hungary lost nearly 75 per cent of its territory and around 33 per cent of ethnic Hungarians found that they no longer lived in Hungary. This trauma was followed by the revisionist interwar era and the years of socialism. In the bipolar world the rigidities of the global order made the question of the minorities became taboos. In the Central and Eastern European region only bilateral agreements ensured the rights of minorities including a weak guarantee of 'classic' core rights (Venice Commission 2002: Chapter B). The implementation of these agreements depended on the given government. Later on the newly adopted democratic constitutions incorporated the relevant international human rights principles. In addition to these guarantees and the role of the home state, emphasized by the international standards, the kin-state, Hungary has also tried to play an active role. For instance, with the 1989 amendment of the Constitution of Hungary the socalled 'responsibility clause' was built in, expressing its responsibility for the fate of ethnic kin in neighbouring countries - itself a trend in the Central and Eastern European 
region. ${ }^{\text {XXXI }}$ After stormy political debates Hungary adopted the Act LXII of 2001 on Hungarians Living in Neighbouring Countries (Status Law) with an overwhelming parliamentary majority (Halász and Majtényi 2002; Küpper 2004: 313.). The goal of the Law, with reference to the responsibility clause, was to create direct links to transborder ethnic Hungarians. It aimed 'to promote and preserve' trans-border Hungarians' 'wellbeing and awareness of national identity within their home country' and to 'ensure undisturbed cultural, economic and family relations'. XxxII The Status Law issued a certificate, called a 'Certificate of Hungarian Nationality' for ethnic Hungarians living in Slovakia, Slovenia, Croatia, Montenegro, Serbia, Romania and Ukraine providing certain benefits on an individual basis in Hungary. Several religious and civil organizations as well as the offices of the RMDSZ (Democratic Alliance of Hungarians in Romania) ${ }^{\mathrm{XXXII}}$ took part in implementing the Status Law. The Status Law caused widespread uproar amongst neighbouring countries. Although Romania had its own Status Law, the country felt, with 6.6 per cent of Hungarians, that its territorial integrity was threatened, and it considered the Law to be an interference with its national, internal affairs.

International bodies like the Council of Europe Venice Commission, the European Parliament and the Organisation for Security and Co-operation in Europe have criticized the Status Law. As for the principle of territorial sovereignty, the Venice Commission was of the opinion that in fields not covered by international treaties or customs, the consent of the home State should be explicit to the kin-State measures on the preferential treatment of its kin-minorities (Venice Commission 2002: Chapter D). In the given case, Romania had not been consulted prior to the adoption of the measure, although the Status Law affected its internal affairs. In addition, the Venice Commission found that part of the Status Law, which authorised semi-official organisations (such as the local representatives of the World Federation of Hungarians, WFH) ${ }^{\text {XxIV }}$ of the kin-state to implement its regulations in the home state particularly troublesome. ${ }^{\mathrm{Xxxv}}$ Moreover, the ethnic targeting of the Status Law was held discriminatory. According to the Status Law the mere declaration of being Hungarian sufficed. ${ }^{\text {Xxxv }}$ The Commission found problematic that it appeared that the organisations representing the Hungarian national community in the neighbouring countries had to investigate the applicant's national background before issuing - or refusing - the relevant recommendation. However, it was not specified in the law what criteria they should apply (Venice Commission 2002: Chapter D/a/ii). The European 
Parliament also criticised the Law. Eric Jürgens, rapporteur of the EP concluded that the Law was 'discriminatory and has extraterritorial implications, and recommended that Hungary should rescind the Law. ${ }^{\text {XxxvII }}$ On behalf of the OSCE Rolf Ekeus High Commissioner for National Minorities highlighted the concern according to which the state can only act within its jurisdiction, meaning its territory and citizenry. ${ }^{\text {XxxvIII }}$ The Hungarian Parliament had to amend the Status Law in order to be in compliance with the above international standards. And although the Romanian government gave its consent to the amended Status Law, the institutions of foreign Hungarians, first and foremost the WFH, were dissatisfied. Other organisations in the neighbouring countries also expressed the need for dual citizenship. For instance, the RMDSZ in Romania and the Democratic Party of Vojvodina Hungarians in Serbia collected signatures and negotiated with the Hungarian Government about the possibility of having Hungarian nationality. However, at that time no Hungarian parliamentary party was supportive of the idea, the officials of the right-wing Fidesz government argued that the Status Law was introduced instead of extending citizenship, which would be 'almost impossible' (Gál 2002: 114).

On 1 May 2004 Hungary - together with some of the neighbouring countries - joined the European Union, but Romania was expected to become a member only at a later stage. Fearing that a different kind of 'Iron Curtain' (Waterbury 2010: 10) would cut off Hungarians in Romania from the homeland, a discussion has started on the possibility of external citizenship.

In 2003 the World Federation of Hungarians came up with the initiative of a referendum, and on 5 December 2004 a referendum was held to grant citizenship to transborder ethnic Hungarians. ${ }^{\text {XXIX }}$ The WFH collected signatures for the referendum, which indicates that at the beginning it was not backed by political parties. It took some time for the right-wing party Fidesz - which previously initiated to adopt the Status Law - to support the referendum. Fidesz's answer to the investigation of the Council of Europe can explain this. Two years earlier Fidesz committed itself not to extend citizenship rights to the Status Law. ${ }^{\mathrm{XL}}$ The then ruling majority, the socialist-liberal coalition was against the referendum all along. The left-wing parties emphasized mainly the possible cost of the country's welfare reform and the probable instability in the region. The possible appearance of new members in the Hungarian political community and its political influence could have been also feared (Kovács 2005: 55-60). After months of negative 
campaigning the result was an invalid referendum. 33 per cent of eligible voters appeared, 51.57 per cent voted in favour of the question (Tóth and Kovács 2007: 144). The referendum failed, which was an unforgivable disappointment for the trans-border ethnic Hungarians. In 2010 the right-wing Fidesz party won the parliamentary elections and shortly afterwards it started to promote strongly, in the words of Prime Minister Viktor Orbán, the 'reunification of the Hungarian nation which was torn apart by the Trianon Peace Treaty' ${ }^{\text {XLI I }}$ It was symbolic that the Act XLV of 2010 on the Testimony for National Cohesion and the amendment of Act LV of 1993 on Hungarian Nationality were the first steps taken by the newly elected government. The Act on National Cohesion declared that all members and communities of the Hungarian nation, subjected to the jurisdiction of other states, belong to the single Hungarian nation. ${ }^{\text {XLII }}$ The amendment of the Act on Hungarian Nationality sought to target ethnic Hungarians living outside Hungary, amending an already existing preferential naturalisation clause and removing the residency requirement. The preferential track allows applicants to naturalise if they demonstrate that their ancestor was a Hungarian national, or their origin from Hungary can be presumed and further provide proof of a sufficient knowledge of the Hungarian language. ${ }^{\text {XLIII }}$ In 2011 a new Constitution, called the Fundamental Law was adopted, including a revised responsibility clause. The responsibility clause appeared in the very first sentence of the preamble and has been expanded in Article D authorising the Hungarian authorities to take action abroad in favour of trans-border ethnic Hungarians. ${ }^{\text {XLIV }}$ Shortly afterwards Hungary provided voting rights to its trans-border citizens. ${ }^{\text {XLV }}$ As a result suffrage is no more subject to registered residence in Hungary. Thereby voters who have never lived in the country could influence general elections. ${ }^{\text {XLVI }}$

Basically we are witnessing a linear development from 2010 till nowadays. The twothird parliamentary majority changed the concept of the nation (Körtvélyesi 2012: 111), indicating a change in the country's relation to the ethnic trans-border Hungarians. The use of the concept of ethnic nation in the Fundamental Law, together with the amendment of the Citizenship Act and the General Elections Act could be understood as part of a resurgence of ethno-cultural nationalism. As Deputy Prime Minister responsible for the policy towards ethnic Hungarians Zsolt Semjén phrased it, the extension of the citizenry and voting rights to ethnic Hungarians without a residency requirement, meant 'the reunification of the nation through the legal system' ${ }^{\text {XLVII }}$ In a statement made before the 
general elections of 2006 the then vice president of Fidesz, István Mikola revealed that the extension of the citizenry and voting rights could have cemented the governance of Fidesz (Mikola 2006). Accordingly, the expressed goal of enfranchising Hungarian minorities was to ensure the survival of the 'one single Hungarian nation' (Fundamental Law) consisting of ethnic Hungarians living anywhere in the region and to secure its own power for twenty years.

\subsection{Implementing the new external citizenship policy}

In what follows we seek to go deeper into the goals that the legislation actually serves with the extension of citizenship and voting rights. As justification constitutes an essential part of the non-discrimination test, here we provide some empirical insights into the functioning of the new policy, as it can be perceived by the target population. First, we evaluate the implementation of the measures concerning the extension of citizenship. Second, we focus on the execution of measures concerning the extension of voting rights.

The 2010 measures concerning the extension of citizenship have simplified the administrative process, resulting in a short, three-month routine procedure, that requires filling some forms and the collection of (birth, marriage and death) certifications proving connection to an ascendant with links to Hungary, as required by the Act, and a handwritten $\mathrm{CV}$ in Hungarian (a standardized language test is not part of the process). Applications can be submitted within the country to the regional representatives of the Office of Immigration and Nationality; registrars; and to the government agencies. Outside of Hungary the consul as the direct representative of Hungary is the person in charge of the process. Should the consul accept the application, it goes to the Minister of Justice, who submits it to the President of the Republic. The President is responsible to issue the certificate of naturalisation. The naturalised person acquires Hungarian citizenship on the day of the oath or pledge of allegiance. ${ }^{\text {XLVIII }}$ In order to implement the measures on preferential naturalisation a complete network was set up in Transylvania. The Hungarian Ministry of Justice and the Hungarian National Council of Transylvania (National Council), a civic organisation supporting the Hungarian minority agreed to lay down the framework.

Back in 2009 the main aim of the National Council was to achieve autonomy and to preserve the integrity of the Hungarians in Transylvania. With this goal in mind, the Council offered its support to the Hungarian minorities in Transylvania regardless of their 
political views. The National Council wished to take the special role as a conciliator between the Transylvanian Hungarian politics and the main public figures. This situation changed substantially after the right-wing Fidesz government came into power in 2010 in Hungary. The National Council set up the new network, called 'Democracy Centres' and established a new party under Romanian law, the Hungarian People's Party of Transylvania (People's Party). ${ }^{\text {Xux }}$ The Democracy Centres were established in order to facilitate 'the reunification process'; they sought to change what they saw as the failed politics of the last 20 years in Romania. ${ }^{\mathrm{L}}$ Since the 1989 democratic transition RMDSZ has represented the Hungarian minority in Romania's political life, sanctioned by votes from the Hungarian minority living in Romania. The National Council and later the People's Party were founded to be the political rivals of RMDSZ, with active support from the Hungarian right-wing government. The truly close relationship between the Hungarian Government and the newly established Transylvanian actors caused significant deficiencies in the operation of the National Council and the Democracy Centres. In order to sketch this fairly knotty situation we chose to conduct interviews with the employees of the People's Party, the National Council and the Democracy Centres in Cluj. Eleven interviews were conducted in 2011 at the National Council, in its regional offices, in the offices of the Democracy Centres and People's Party in Cluj. We talked to the Executive Director responsible for financial and organisational matters of the National Council as well as administrators in regional offices of the National Council. Employees of the Democracy Centres responsible for implementing the naturalisation process were also interviewed, as well as the Head of Secretariat of the People's Party who talked about his experience in connection with the preferential naturalisation.

The interviews shed light on confusion of duties, responsibilities, facilities and budgets of the different organisations. The Head of the Secretariat of the People's Party was responsible both for managing the People's Party office, and for the hotline of the Democracy Centre. ${ }^{\text {LI }}$ Employees of the National Council are formally hired by the offices of the Democracy Centres; yet, they were at the same time in charge of the duties of the People's Party. The Executive Director responsible for the financial and organisational matters of the National Council's office admitted that their job focused primarily on National Council cases, but in their spare time they also dealt with People's Party related issues. ${ }^{\text {LII }}$ As per the financial support concerns, the Executive Director made it clear that 
neither Hungarian nor Romanian organisations financed the People's Party directly. The People's Party itself did not even have any employee. The Director also confirmed that it was the National Council which received financial support from the Hungarian State.

These interviews lead us to the conclusion, however, that due to the intense relationship between the National Council and the People's Party, financing a civic organisation (the National Council) meant a Hungarian governmental support to a Romanian Party.

The amalgamation of the three organisations frustrated the goals of the National Council to support everyone regardless of their political views. The Democracy Centres failed to comply with their duties other than providing support connected to the naturalisation. They were meant to assist the applicants in submitting a naturalisation request, however, in practice, employees were filling out the complete application forms and book appointments at the Consulate, and sometimes they also helped to complete the handwritten CVs. This meant that the same employees had full control over the process, also being able to filter applicants. The official explanation was that the organisations representing Hungary beyond the borders were in position of investigating the applicant's Hungarian knowledge before submitting the application package to the Consulate. In reality, the process seems to be used to gain support for a political party in two respects. First, by showing that the implementation of the law is in the hands of people connected to the People's Party that is close to the Hungarian ruling party but not supported by the majority of the Hungarian voters in Romania. Even if we accept that these employees can act in the name of the Hungarian state in such a way, the confusion of duties that we encountered puts into question the neutrality of the process that one could expect from a state procedure to accept new nationals. Second, by providing funds which in part were used for political campaigns in the Romanian elections. The network of the three organisations exercised state power extraterritorially and they worked under political influence coming from the Hungarian ruling party. All this seems to frustrate the goal of genuine reunification, and looks more like exporting political divisions from Hungary.

Last but not least we sketch out what role the discussed organisations played in connection with the extension of voting rights. The strong relationship between the Hungarian Government and the People's Party can hardly pass unnoticed. ${ }^{\text {LIII }}$ The People's Party campaigned for a year to get trans-border Hungarians register and it offered help 
during the elections as well. On the day of the 2014 general elections the number of the trans-border registered voters was 193,793, out of which 66.42 per cent participated in the elections. 128,429 voting slips proved to be valid, and 122,638 voted for Fidesz. ${ }^{\text {LIV }}$ It was with the help of these votes that the right-wing Fidesz gained again the constitutionamending two-thirds majority of the seats in the Hungarian Parliament. The People's Party together with the National Council helped to deliver two-thirds of the registrations and almost two-thirds of the Transylvanian votes.

As we have seen earlier by extending the citizenry one of the main aims of the Hungarian ruling party was exactly this: to cement its own power for a longer period. The idea to extend the citizenry beyond the state borders is not a new one; it actually marks a regional trend, a model that was certainly known before the Hungarian decision-makers. The ruling parties of Hungary's neighbouring countries have also counted on the external votes, e.g., in 2007 in Croatia, 10 per cent of the voters participated in the general elections were trans-border citizens. Or, in the 2009 Romanian presidential elections, the external votes came from trans-border citizens living in Moldova and Ukraine helped Traian Basescu to be elected as president (Pogonyi et al. 2010: 14-15). However the move was used to provide support not only to one civic organisation (the National Council) but also to a political party established and operated under Romanian law. This was holding the People's Party up, which in exchange launched a major political campaign benefiting Fidesz. However, the consequences are disturbing. The governmental aim of uniting the Hungarian nation certainly failed as a result of the recently launched preferential naturalisation process. We would not be able to count on one hand how many different groups of Hungarians can now be identified in Transylvania, from the perspective of Hungarian law adopted by the various Fidesz governments. There are ethnic Hungarians who live in Transylvania as Romanian citizens, there are Status Hungarians, the ones with dual (Hungarian-Romanian) nationality; those who registered to vote, those who voted, and those who did not. Indeed, one explanation to the high number of votes going to Fidesz in 2014, in addition to gratitude for the extension of citizenship, is that the road to Hungarian elections is multi-layered. Not all ethnic Hungarians are interested in getting non-resident nationality, even less consider that they should participate in the elections of a neighbouring country, the Hungarian kin-state, so not all of them register for voting, and 
even less actually cast a vote. ${ }^{\text {LV }}$ This works as a filter that can easily be biased towards those who are anyway motivated by the nationalist rhetoric of Fidesz.

As a result, the Hungarian Government exported the Hungarian political divisiveness beyond the borders and it managed to organise and support a well-structured system for this in Romania. In addition, the Hungarian Government, by trying to earn support for itself and for the newly established People's Party, did not take the will of the ethnic Hungarians in Transylvania seriously, as it used the naturalisation process to provide support for a particular political party in Romania. This is in itself problematic, but also questions the sincerity of the Hungarian Government in demanding territorial autonomy for the Hungarian minority group in Transylvania. ${ }^{\text {LVI }}$

According to László Kövér, Speaker of the Parliament of Hungary, from 2014, the Parliament is more than a national assembly, since it is the first one that represents the whole nation. ${ }^{\text {LVII }}$ This sounds like a break with the notion that the notion of the cultural nation ('the whole nation' here) applies to all regardless of citizenship, and this understanding certainly contravenes the goal of reunification. The majority of ethnic Hungarians living in neighbouring countries did not apply for Hungarian citizenship and/or did not register for voting. The quoted statement seems to push these people outside of the national community described as 'the whole nation'.

\section{Conclusions}

In this paper we argued that the general non-discrimination test should be applied to naturalisation policies, including external ethnic citizenship policies. Since classification based upon ethnicity is a suspect one, heightened scrutiny is required to filter out discriminative state measures. The relevant normative, human rights test examines whether the ethnic classification applied is proportionate to the legitimate aim. Therefore, the paper looked into possible goals (ethno-cultural ties as genuine link, nationality as an expression of 'national identity', oppressive policies of the home state, remedying discrimination flowing form the past, social integration, virtualising borders) the state can legitimately seek to achieve by implementing external ethnic citizenship policies. These are the possible justifications that are the most likely to succeed on a non-discrimination test. However, in addition to these prima facie acceptable justifications for external ethnic citizenship policies, 
illegitimate policy goals can be identified, which are not relevant for the non-discrimination test, as they would immediately fail the scrutiny. Often what is really working in the background is a nation-building project that seeks to revisit history, to the extent possible, and ('re-') establish a desired past through the means of citizenship policies. One of the main goals of the recent extension of citizenry and voting rights in Hungary was the 'reunification of the Hungarian nation'. However, Hungary's external citizenship regulation and its implementation did not help to create unity rather it caused divisiveness. The majority of trans-border ethnic Hungarians did not apply for Hungarian citizenship and/or did not register for voting. The applied policy and the implementation process seem to push these people outside of the national community described as the whole nation. All this seems to frustrate the goal of genuine reunification, and looks more like exporting political divisions from Hungary and seeking to secure a loyal voting base.

\footnotetext{
* Kriszta Kovács PhD is associate professor at ELTE University European Studies Department and Research Fellow at the University of Trento (CoPolis Project). She is also a senior adviser of the Hungarian Constitutional Court (between 2013-15 on unpaid leave), and Co-President of the Joint Council on Constitutional Justice (Venice Commission, Council of Europe). In 2000/2001 she was a visiting research fellow at the Human Rights Institute of the Columbia Law School. She has published several articles on constitutional law, human rights and discrimination including a monograph on equality. - Zsolt Körtvélyesi holds a law degree from Szeged University, a Nationalism Studies MA degree from Central European University and an LLM degree from Harvard Law School. He is now working on his SJD thesis at the Comparative Constitutional Law Program of the Central European University. Körtvélyesi is assistant professor at ELTE University European Studies Department and a junior researcher at the Institute for Legal Studies of the Hungarian Academy of Sciences Centre for Social Sciences. He has published articles and book chapters on topics including data protection, property rights, freedom of assembly, minority rights, nationality and citizenship. - Aliz Nagy holds an MA degree in international relations (specialised in international human rights) BA degrees in History and Slavonic Studies form ELTE University. Currently she is a PhD candidate at the Doctoral School of Sociology, ELTE University. Her main fields of interest include citizenship and nation policy theories and more specifically, the issue of dual citizenship, civic and political life in Transylvania. She has conducted research on the situation of trans-border Hungarians during the empire changes in Partium.

I See Article 15 of the Universal Declaration of Human Rights.

II The EU law will not be addressed here directly. We try to build on principles that apply generally, outside the quite specific case of the EU. Many countries applying similar policies are not EU Member States. III Dumbrava writes most recently, along the same lines, about 'public relatives' (Dumbrava 2014: 47).

IV Many constitutional courts apply the term positive discrimination, in the European Union it is positive action, in Canadian legal literature positive policy, and in the United States it is called affirmative action, preferential treatment or reverse discrimination. In the present article we are using the term preferential treatment. With this term we mean those measures that give an advantage to individuals on the basis of their belonging to certain national or ethnic minorities or a social group in a special, disadvantageous situation.

v See, e.g. Karassev v. Finland, no. 31414/96, ECHR 1999-II.

VI This is already a huge achievement in the case of the secrecy and non-contestability of naturalisation decisions, as is the case with Hungary.

VII See the legal dimension of citizenship in Carens 2000: 162, cited in Dumbrava 2014: 6: 'a formal status that links individuals to particular states and preconditions a set of rights and duties" (emphasis added).

VIII See Lincoln's Gettysburg Address: 'of the people, by the people, for the people'.
} 
IX For instance, Hungary and Romania allow external naturalisation combined with non-resident voting rights, Croatia has a sizeable non-resident voting kin population as well as Italy, applying a separate regime for voting external citizens. Furthermore, it is not exceptional that external votes turn out to be decisive. For a broader overview, see Pogonyi et al. 2010.

$\mathrm{x}$ 'It is for each State to determine under its own law who are its nationals. This law shall be recognised by other States in so far as it is consistent with international conventions, international custom, and the principles of law generally recognised with regard to nationality.' Art. 1., Convention On Certain Questions Relating to the Conflict of Nationality Laws, The Hague, 12 April 1930.

xI Nottebohm (Liechtenstein v. Guatemala) ICJ, No. 18 General List (1955), p. 24.

XII European Convention on Nationality, Council of Europe, No. 166, Strasbourg, 6 November 1997.

XIII Art. 2.a, European Convention on Nationality, Council of Europe, No. 166, Strasbourg, 6 November 1997. Note that this, in itself, does not mean that the person's ethnic origin cannot be taken into consideration either.

XIV 'The rules of a State Party on nationality shall not contain distinctions or include any practice which amount to discrimination on the grounds of sex, religion, race, colour or national or ethnic origin.' Art. 5.1, European Convention on Nationality, Council of Europe, No. 166, Strasbourg, 6 November 1997.

xv See, e.g. Kurić and Others v. Slovenia [GC], no. 26828/06, \386, ECHR 2012.

xvi See Kurić and Others v. Slovenia [GC], no. 26828/06, \ 386, ECHR 2012, citing Oršuš and Others v. Croatia [GC], no. 15766/03, \156, ECHR 2010.

XVII See D.H. and Others v. the Czech Republic [GC], no. 57325/00, \175, ECHR 2007.

XVIII Art. 11(1), Act No. 21/1991 on Romanian Nationality as republished, with amendments, on 10 February 2010, for an English version, see citizenship.eu/NationalDB/docs/ROM $\% 20$ Citizenship $\% 20$ Law $\% 201991 \% 20 \% 28$ English consolidated $\% 20$ version $\% 2017 \% 20 \mathrm{June} \% 202010 \% 29$.pdf; Art. 4(3), Act LV of 1993 on Hungarian Nationality, as amended by Act XLIV of 2010, for a bilingual version, see http://eudocitizenship.eu/NationalDB/docs/HUN $\% 20$ Act $\% 20 L V \% 20$ of $\% 201993 \% 20 \% 28$ as $\% 20$ of $\% 20$ Jan $\% 202009, \%$ 20English \%29.pdf.

XIX See, e.g. Kurić and Others v. Slovenia [GC], no. 26828/06, 』 387, ECHR 2012, citing Ünal Tekeli v. Turkey, no. 29865/96, \54, ECHR 2004-X.

xx For some European examples see Dumbrava 2014: 40-41. Sejdić and Finci v. Bosnia and Herzegovina [GC], no. 27996/06, 34836/06, ECHR 2009, for the relevant statement on necessity and proportionality, see $\int 46$.

XXI See the list based on the considerations of the International Court of Justice in the Nottebohm decision: 'a legal bond having as its basis a social fact of attachment, a genuine connection of existence, interests and sentiments, together with the existence of reciprocal rights and duties'. Nottebohm, ICJ Reports 1955, p. 23, cited in the Explanatory Report of the European Convention on Nationality, para. 22. 'At the time of his naturalization does Nottebohm appear to have been more closely attached by his tradition, his establishment, his interests, his activities, his family ties, his intentions for the near future to Liechtenstein than to any other State?', Nottebohm, p. 24.

XXII See the 'social integration' arguments under 5 below.

XXIII For accounts driven by similar concerns, see Bolzano Recommendations 2008 and Venice Commission 2002.

XXIV For an elaborate discussion on the problem of securitization, with examples from the region we are discussing here, see Kymlicka 2007: 182-195, concluding that whenever the 'security card' is played, it trumps minority rights.

xxv See e.g. Bárdi 2004, talking about external citizenship as an illusion, the 'blue bird of hope'.

Xxvi For an overview of what kin-states can do, see Venice Commission 2002.

XXVII For more details on these policies, see, respectively, Tóth and Kovács 2013; Iordachi 2013; Barbulescu

2013. ECHR case law recognizes and might even require the correction of 'factual inequalities'. See the principled invoked in the context of nationality in Kurić and Others v. Slovenia, [GC], no. 26828/06, \388, ECHR 2012.

XxvIII See the principled invoked in the context of nationality in Kurić and Others v. Slovenia, [GC], no. 26828/06, \388, ECHR 2012. 
XXIX It is a separate question whether this violation is remedied through levelling down, easing the rules for non-preferential applicants, or by levelling up, hardening the requirements for the preferential track, or else by doing a bit of both.

xxx 330,970 out of 500,097 applications for preferential naturalisation http://www.allampolgarsag.gov.hu/index.php?option=com content\&view=article\&id=274:hirek130909\&ca

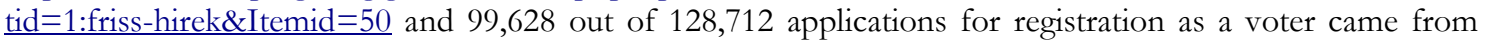
Romania. http://www.valasztas.hu/hu/ogyv2014/766/766 5 1.html.

xxxI Art. 6(3) 'The Republic of Hungary bears a sense of responsibility for the fate of Hungarians living outside its borders and shall promote and foster their relations with Hungary.' For a list of 'national responsibility clauses', see Pogonyi et al. 2010: 3; Halász and Majtényi 2002: 135-144. Most of these countries introduced so-called 'status laws' for external kin minorities, see Bauböck 2007: 2396.

XXXII Act LXII of 2001 on Hungarians living in neighbouring countries, Chapter II Article 4.

XXXIII RMDSZ is a Hungarian Party in Romania with the largest number of supporters; several times a governing party in Romania from 1996.

XXxIV The WFH is a specific, marginalized organization without strong internal support, and not very well integrated into domestic Hungarian policies. Its ambition is to join all the Hungarians in the World, preserve and promote their culture.

xxxv 'The grant by a State of administrative, quasi-official functions to non-governmental associations registered in another country constitutes an indirect form of state power: as such, it is not permissible unless specifically allowed.' Venice Commission 2002: Chapter D a/ii.

xxxvi Art. 1(1) 'This Act shall apply to persons declaring themselves to be of Hungarian nationality who are not Hungarian citizens and who have their residence in the Republic of Croatia, the Federal Republic of Yugoslavia, Romania, the Republic of Slovenia, the Slovak Republic or the Ukraine...'.

XXXVII Doc. 9744 rev. 13 May 2003, Preferential treatment of national minorities by the kin-state: the case of the Hungarian law of 19 June 2001 on Hungarians living in neighbouring countries http://assembly.coe.int/ASP/Doc/XrefViewHTML.asp?FileID=10094\&Language=EN.

XXXVIII 'Sovereignty, Responsibility, and National Minorities,' Statement by Rolf Ekeus, OSCE High Commissioner on National Minorities, in The Hague, 26 October 2001. http://www.osce.org/hcnm/53936 Xxxix 'Do you think that Parliament should pass a law allowing Hungarian citizenship with preferential naturalization to be granted to those, at their request, who claim to have Hungarian nationality, do not live in Hungary and are not Hungarian citizens and who prove their Hungarian nationality by means of a 'Certificate of Hungarian Nationality' issued pursuant to Article 19 of Act LXII of 2001 or in another way to be determined by the law which is to be passed?' www.election.hu cited by Tóth, Kovács 2007: 143.

XL Opinion 168/2001, Strasbourg, Paper Containing the Position of the Hungarian Government in Relation to the Act on Hungarians Living in Neighbouring Countries http://www.venice.coe.int/webforms$\angle$ documents/?pdf $=$ CDL $\% 282001 \% 29080-$ e.

XLI Excerpt from the speech of Viktor Orbán in the Hungarian Public Radio on 25 April 2004. See the website of the chronology of the dual citizenship http://www.kettosallampolgarsag.mtaki.hu$\angle$ kronologia.html

XLII Art. 3 of the Act XLV of 2010 on the Testimony for National Cohesion. http://www.vajma.info/docs/Nemzeti-osszetartozas-torveny.pdf.

XLIII Art. 4(3) 'A non-Hungarian citizen who resides in Hungary and declares himself or herself to be of Hungarian nationality and whose ascendant was a Hungarian citizen may be naturalized on preferential terms upon his or her application in case the conditions defined in Subsection (1) paras b) to e) are satisfied.'

XLIV Art. D 'Bearing in mind that there is one single Hungarian nation that belongs together, Hungary shall bear responsibility for the fate of Hungarians living beyond its borders, and shall facilitate the survival and development of their communities; it shall support their efforts to preserve their Hungarian identity, the assertion of their individual and collective rights, the establishment of their community self-governments, and their prosperity in their native lands, and shall promote their cooperation with each other and with Hungary.' XLV Article 7(3) of the Act CCIII of 2011 on the Elections of Members of Parliament allows voters without residence in Hungary to vote for one party list.

XLVI Itself a regional trend, see examples from Croatia, Italy and Romania. Dumbrava 2014.

XLVII See Szalay Tamás Lajos, 320,000 ethnic Hungarians in neighbouring countries got Hungarian citizenship with voting rights in two years, Budapest Telegraph based on Népszabadság, 
http://www.budapesttelegraph.com/news/285/320 000 ethnic hungarians in neighboring countries got hungarian citizenship with voting rights in two years.

XLVIII See Articles 13-18 of the Act LV of 1993 on Hungarian Citizenship.

XuIx Offices of the Democracy Centres http://www.emnt.org/demokracia kozpontok.html; Decision on establishing the Hungarian People's Party in Transylvania, http://www.emnt.org/admin/dataLfile/20130318/emnp hatarozat emnt.pdf.

L The Political Framework Programme of the Hungarian People's Party of Transylvania http://www.neppart.eu/admin/data/file/20120222/keretprogramweb.pdf.

LI Interview in Cluj with the Head of Secretariat of the office of the People's Party in August 2011 (on file with the authors).

LII Interview in Cluj with the Executive Director responsible for the financial and organisational matters of the National Council in August 2011 (on file with the authors).

LIII The People's Party congratulates to the victory of Fidesz and happily undertakes its contribution to it. http://www.neppart.eu/az-erdelyi-magyar-neppart-gratulal-a-fidesz-kdnp-valasztasi-gyozelmehez.html

LIV See National Election Office, Information on counting the votes delivered by postal ballot for lists, Parliamentary Elections, 6 April 2014, http://www.valasztas.hu/dyn/pv14/szavossz/en/levjkv_e.html. This includes external nationals voting from other countries, not only Romania. No data is available on a country basis.

LV See numbers work out as follows. There are several millions of ethnic Hungarians living in the countries neighbouring Hungary. Around half a million people applied for Hungarian nationality (note that this was less at the time of the 2014 elections), 195,338 registered to vote, and 128,429 cast a valid vote. For the number on registration, not cited earlier, see National Election Office, Number of registered non-resident voters, Parliamentary Elections, 6 April 2014, http://valasztas.hu//hu/ogyv2014/766/766 5 2.html.

LVI See http://sznt.sic.hu/en/index.php?option=com content\&view=article\&id=214\%3Ahungariangovernment-supports-szekler-county-autonomy\&catid=18\%3Acikkek-tanulmanyok\&Itemid=24\&lang=en.

LVII See the opening statement on the official site of the Hungarian Parliament: parlament.hu: 'Magyarország történelmében ez az első képviselőház, amelyik az általános, titkos és egyenlő választójog alapján az egész nemzetet képviseli - azaz, több mint Országgyúlés.'

\section{References}

- Bárdi Nándor, 2004, “AA mumusok és a kék madár” Mi történt? Miről beszél(t)ünk?’, Interview by Gyöngyi Annamária, Regio 2004/4, 51-84, available at http://epa.oszk.hu/00000/00036/00056/pdf/5184.pdf (accessed: 15 Jan. 2015).

- $\quad$ Bauböck Rainer, 2006, Migration and Citizenship. Legal Status, Rights and Political Participation, University Press, Amsterdam.

- Bauböck Rainer, 2007, 'Stakeholder Citizenship and Transnational Political Participation: A Normative Evaluation of External Voting', Fordham Law Review LXXV(4): 2393-2447

- Bauböck Rainer, 2010, 'Dual citizenship for transborder minorities? How to respond to the Hungarian-Slovak tit-for-tat' in Rainer Bauböck (ed), Dual citizenship for transborder minorities? How to respond to the Hungarian-Slovak tit-for-tat, EUI Working Papers RSCAS 2010/75, Badia Fiesolana (FI), 1-4, available at http://cadmus.eui.eu/bitstream/handle/1814/14625/RSCAS 2010 75.corr.pdf?sequence=3 (accessed 28 Jan. 2015).

- $\quad$ Blatter Joachim, 2010, 'Dual citizenship for ethnic minorities with neighbouring kin states', EUDO Citizenship Observatory, in Rainer Bauböck (ed), Dual citizenship for transborder minorities? How to respond to the Hungarian-Slovak tit-for-tat, EUI Working Papers RSCAS 2010/75, Badia Fiesolana (FI), 13-18, available at http://cadmus.eui.eu/bitstream/handle/1814/14625/RSCAS 2010 75.corr.pdf?sequence=3 (accessed 28 Jan. 2015).

- Brubaker Rogers, 1996, Nationalism Reframed: Nationhood and the National Question in the New Europe, Cambridge University Press, Cambridge.

- Carens Joseph H., 2000, Culture, Citizenship, and Community. A Contextual Exploration of Justice as Evenhandedness, Oxford University Press, Oxford.

- Dumbrava Costica, 2014, Nationality, Citizenship and Ethno-cultural Belonging. Preferential Membership 
Policies in Europe, Palgrave.

- Dworkin Ronald, 2011, Justice for Hedgehogs, Belknap, Cambridge, Mass.

- Gál Kinga, 2002, 'The Hungarian Legislation on Hungarians Living in Neighbouring Countries', in The Protection of National Minorities by their Kin-State, Venice Commission, Science and technique of democracy, No. 32, Council of Europe, Strasbourg.

- Halász Iván and Majtényi Balázs, 2002, 'Constitutional Regulation in Europe on the Status of Minorities living abroad' in Minorities research (4) 135-144.

- Iordachi Constantin, 2013, Country Report: Romania, EUDO Citizenship Observatory, 2009, revised and updated April 2013, available at $\underline{\text { http://eudo- }}$ citizenship.eu/admin/?p=file\&appl=countryProfiles\&f=2013-19-Romania.pdf (accessed 27 Jan. 2015).

- Joppke Christian, 2005, Selecting by Origin, Ethnic Migration in the Liberal State, Harvard University Press, Cambridge, Mass.

- Kántor Zoltán, 2004, 'Status Law and 'Nation Policy': Theoretical Aspects' in Kántor Zoltán, Majtényi Balázs, Ieda Osamu-Vizi, and Balázs-Halász Iván (eds), The Hungarian Status Law: Nation Building and/or Minority Protection, Slavic Research Center, Hokkaido University, Sapporo, Budapest, 303-309

- Kovács M. Mária, 2005, 'The Politics of Nonresident Dual Citizenship in Hungary', in Regio (1): 50-

72.

- Körtvélyesi Zsolt, 2012, "From "We the People" to "We the Nation"” in Tóth Gábor Attila (ed), Constitution for a Disunited Nation. On Hungary's 2011 Fundamental Law, CEU Press, Budapest-New York.

- Küpper Herbert, 2004, 'Hungary's Controversial Law' in Kántor Zoltán, Majtényi Balázs, Ieda Osamu, Vizi Balázs, and Halász Iván (eds), The Hungarian Status Law: Nation Building and/ or Minority Protection, Slavic Research Center, Hokkaido University, Sapporo, Budapest, 313-327.

- $\quad$ Kymlicka Will, 2007, Multicultural Odysseys. Navigating the New International Politics of Diversity, Oxford University Press, Oxford.

- Mikola István, 2006, 'Nemcsak négy, hanem húsz évre kell nyernünk', in hvg.hu, available at http://m.hvg.hu/app//valasztas2006/20060319mikola.

- Nagel Thomas, 2005, 'The Problem of Global Justice’, in Philosopby \& Public Affairs, 33 (2): 113-147.

- Pogonyi Szabolcs, Kovács M. Mária, Körtvélyesi Zsolt, 2010, 'The Politics of External Kin-State Citizenship in East Central Europe', Comparative Report, RSCAS/EUDO-CIT-Comp. 2010/6, European University Institute, Robert Schuman Centre for Advanced Studies, EUDO Citizenship Observatory (Florence, October 2010) http://eudo-citizenship.eu/docs/ECEcompreport.pdf.

- $\quad$ Rawls John, 1993, 'The Law of Peoples' in Critical Inquiry 20 (Autumn 1993): 36-68.

- Shachar Ayelet, 2012, 'Citizenship', in Rosenfeld Michel and Sajó András (eds), The Oxford Handbook of Comparative Constitutional Law, Oxford University Press, Oxford, 1002-1019.

- $\quad$ Shevel Oxana, Kusá Dagmar, Barbulescu Roxana, 2010, 'EUDO Citizenship, Reactions in Ukraine, Slovakia, Romania, Serbia to Hungary's Decision to Give Access to Citizenship to Ethnic Hungarians’ May 23, 2010 http://eudo-citizenship.eu/citizenship-news/306-hungarian-government-proposes-access-tocitizenship-for-ethnic-hungarians-in-neighbouring-countries.

- $\quad$ Stone Geoffrey R., Seidman Louis M., Sunstein Cass R. and Tushnet Mark V., 1996, Constitutional Law, Aspen Publishers.

- Tóth Judit and Kovács M. Mária, 2013, 'Country Report: Hungary', EUDO Citizenship Observatory, 2009, revised and updated April 2013, citizenship.eu/admin/?p=file\&appl=countryProfiles\&f=2013-18-Hungary.pdf.

- Tóth Judit and Kovács M. Mária, 2007, 'Hungary: Kin-state Responsibility and Ethnic Citizenship: The Hungarian Case' in Bauböck Rainer, Perchinig Bernhard, and Sievers Wiebke (eds), Citizenship Policies in the New Europe, Amsterdam University Press, 135-158.

- Vink Maarten P. and de Groot Gerard-René, 2010, Birthright Citizenship: Trends and Regulations in Europe, EUDO Citizenship Observatory.

- Waterbury Myra A., 2010, Between State and Nation. Diaspora Politics and Kin-state Nationalism in Hungary, Palgrave Macmillan, New York. 


\section{International documents}

- Bolzano Recommendations, 2008, Organization for Security and Co-operation in Europe, High Commissioner on National Minorities, The Bolzano/Bozen Recommendations on National Minorities in Inter-State Relations \& Explanatory Note, June 2008, http://www.osce.org/hcnm/33633.

- Convention On Certain Questions Relating to the Conflict of Nationality Laws, The Hague, 12 April 1930.

- $\quad$ European Convention on Nationality, Council of Europe, No. 166, Strasbourg, 6 November 1997.

- Venice Commission, 2002, European Commission for Democracy Through Law, The Protection of National Minorities by their Kin-State, Report no. CDL-STD(2002)032, adopted in Athens, 7-8 June 2002, http://www.venice.coe.int/webforms/documents/?pdf=CDL-STD $\% 282002 \% 29032$-bil.

\section{Case law}

- ICJ, Nottebohm (Liechtenstein v. Guatemala), No. 18 General List (1955)

- $\quad$ ECHR., D.H. and Others v. the Czech Republic [GC], no. 57325/00, 2007

- $\quad$ ECHR., Kurić and Others v. Slovenia, [GC], no. 26828/06, 2012

- $\quad$ ECHR., Oršuš and Others v. Croatia [GC], no. 15766/03, 2010

- $\quad$ ECHR., Sejdić and Finci v. Bosnia and Herzegovina [GC], no. 27996/06, 34836/06, 2009

- $\quad$ ECHR., Ünal Tekeli v. Turkey, no. 29865/96, 2004-X

\section{Legislation}

- $\quad$ Act No. 21/1991 on Romanian Nationality as republished, with amendments, on 10 February 2010

- $\quad$ Act LV of 1993 on Hungarian Nationality, as amended by Act XLIV of 2010

- $\quad$ Act LXII of 2001 on Hungarians Living in Neighbouring Countries

- $\quad$ Act XLV of 2010 on the Testimony for National Cohesion

- Act CCIII of 2011 on the Elections of Members of Parliament

- Act XXXVI of 2013 on Electoral Procedure 